\title{
THE LOWER PLIOCENE ELASMOBRANCH ASSEMBLAGE FROM ARCILLE (CAMPAGNATICO, GROSSETO PROVINCE): PALAEOECOLOGICAL PALAEOENVIRONMENTAL
} SIGNIFICANCE

\author{
Marco Merella $^{1}$, Alberto Collareta $^{1}$, Simone Casati ${ }^{2}$, Andrea Di Cencio ${ }^{2,3}$, Walter Landini ${ }^{1}$, \\ Giovanni Bianucci ${ }^{1}$ \\ ${ }^{1}$ Dipartimento di Scienze della Terra, Università di Pisa, via Santa Maria 53, 56126, Pisa, Italy; \\ ${ }^{2}$ G.A.M.P.S. gruppo AVIS mineralogia e paleontologia SCANDICCI, piazza Vittorio Veneto 1, Badia a Settimo (Scandicci, FI), Italy; \\ ${ }^{3}$ Geology \& Paleontology Technical Studio, via Fratelli Rosselli 4, San Casciano Val di Pesa (FI), Italy.
}

\author{
KeYwORDS: \\ Elasmobranchii; \\ palaeoecology; \\ palaeoichthyology; \\ Mediterranean Sea; \\ Zanclean.
}

\section{Bullet-Points Abstract}

- Tuscany hosts a conspicuous fossil record of elasmobranchs.

- New stratigraphically informed studies are need to be performed.

- A newly discovered elasmobranch assemblage is described from the lower Pliocene Campagnatico locality.

- This diverse assemblage allows for a reconstruction of an early Pliocene marginal-marine palaeoenvironment of Tuscany.

\section{INTRODUCTION}

For almost two centuries, the Pliocene marine successions of Tuscany have been the location of important finds of fossil remains of elasmobranchs, mostly shark teeth and batoid dental plates and dermal spines. These fossils were collected to form important collections, in the past the subject of studies by illustrious palaeontologists (Lawley, 1876). Following the emergence of modern palaeontological research standards, however, these historical collections have lost some of their scientific importance due to widespread uncertainties regarding the geographical and stratigraphic contextualization of the material of which they are comprised. The collection of new material with a more rigorous methodological approach is thus crucial for allowing to better highlight the scientific value of this important part of the palaeontological heritage of the Tuscan territory. With the present study, a stratigraphically informed analysis of the elasmobranch assemblage found in the Zanclean sands exposed near Arcille (Campagnatico, GR) was carried out in order to reconstruct the palaeobiological and palaeoenvironmental context that characterized the Tuscan coasts during the lower Pliocene. The sediments exposed at Arcille were deposited around 5.1-4.5 Ma within the BaccinelloCinigiano Basin (Benvenuti et al., 2001) and reflect depositionin submerged delta and shelf settings. Among the Pliocene marine vertebrate-bearing localities of
Tuscany, Arcille is of particular importance, as it is the site of the discovery of 1) numerous skeletons of the dugongid sirenian $†$ Metaxytherium subapenninum, 2) the holotype and only known specimen of the archaic monodontid cetacean †Casatia thermophila, and 3) two partial skeletons of marlin (Makaira sp.) (Bianucci et al., 2019).

\section{Materials ANd Method}

The elasmobranch assemblage from Arcille, reconstructed on the basis of more than 300 teeth and dermal spines, includes 24 species of sharks and rays in 13 families (Hexanchidae, Squatinidae, Carcharhinidae, Scyliorhinidae, Triakidae, Cetorhinidae, Alopiidae, Lamnidae, Odontaspididae, Dasyatidae, Myliobatidae, Rajidae and Rhinobatidae) in 7 orders and 4 superorders. An excerpt of the elasmobranch remains from Arcille is depicted in Fig. 1.

\section{Discussion and Concluding Remarks}

Of particular interest is the identification of taxa such as $\dagger$ Pachyscyllium dachiardii, and $\dagger$ Megascyliorhinus miocaenicus: indeed, the post-Miocene fossil record of these species in the Mediterranean Basin is extremely fragmentary, and as such, their occurrence at Arcille represents an important datum that supports the

Corresponding autor's contact: marcomerella1994@gmail.com

How to cite: Merella et al. (2020). The lower Pliocene elasmobranch assemblage from Arcille (Campagnatico, Grosseto Province): palaeoecological and palaeoenvironmental significance. Fossilia, Volume 2020: 41-43. 


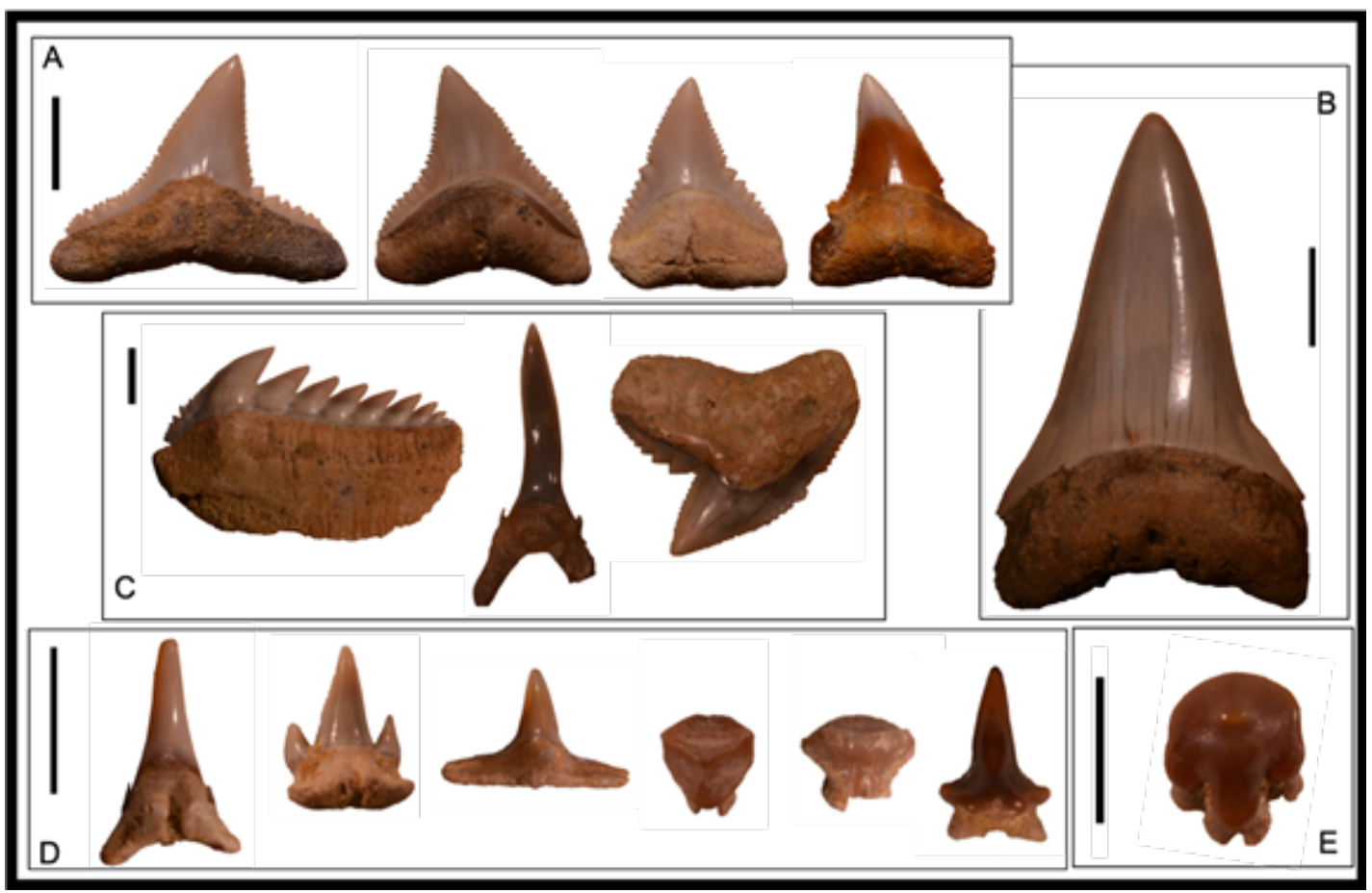

Fig. 1. Shark and ray teeth from the Zanclean of Arcille (Campagnatico, Grosseto Province). A) From left to right: Carcharhinus brachyurus, Carcharhinus leucas, Carcharhinus falciformis and Prionace glauca. B) Cosmopolitodus plicatilis. C) From left to right: Hexanchus griseus, Carcharias taurus and Galeocerdo cuvier. D) From left to right: Megascyliorhinus miocaenicus, Pachyscyllium dachiardii, Squatina sp., Himantura sp., Dasyatis sp. and Rostroraja sp. E) Rhinobatos sp. teeth of Himantura sp., Dasyatis sp. and Rhinobatos sp. are depicted in occlusal view, all other teeth are depicted in lingual view. Scale bars equal $5 \mathrm{~mm}$, except for panels $\mathrm{B}(10 \mathrm{~mm})$ and $\mathrm{E}(1 \mathrm{~mm})$.

regional permanence of Miocene- and Tethyan-derived faunal elements in the aftermath of the so-called Messinian Salinity Crisis. An interesting element is represented by the finding, among the myliobatiforms, of specimens whose dental morphology is consistent with that of the Indo-Pacific members of the genus Himantura. The species of this genus are currently distributed in the coastal waters of the Indo-Pacific and western Atlantic oceans. Nowadays, only one species of Himantura (i.e., Himantura uarnak see Ali et al., 2013) lives in the Mediterranean Sea. Whereas the current presence of Himantura in the present-day Mediterranean waters is linked to the opening of the Suez Canal (i.e., it is a "lessepsian migrant"), its discovery in the Mediterranean Pliocene is less easily explainable, as it could suggest either ephemeral connections between the Indo-Pacific and the Mediterranean waters in Pliocene times or the persistence of a Tethyan-derived Mediterranean Himantura as a "ghost lineage" following the closure of the Eastern Tethys Seaway. Besides this elasmobranch assemblage, the first steps of this work have led to the discovery of a large number of teeth of bony fishes (sparids, sphirenids and labrids) and of a diverse mollusk assemblage that includes $†$ Callista italica and $\uparrow$ Pelecyora gigas, two extinct venerids that characterise the lower Pliocene shelfal oryctocoenoses of the Mediterranean region.

On the basis of the studied assemblage, it is possible to propose a palaeoecological framework of the Arcille sea area during the Zanclean. The presence of the bull shark (Carcharhinus leucas) and the bull ray (Aetomylaeus bovinus) suggests a shallow-marine palaeoenvironment, close to a river mouth (Compagno, 1984; Villafaña et al., 2019), whereas the bluntnose sixgil shark (Hexanchus griseus), the bigeye thresher shark (Alopias superciliosus) and marlin indicate strong connections with open-sea and deep-water habitats (Castro et al, 1999; Nakano et al., 2003). Furthermore, the presence of the bull ark and tiger shark (Galeocerdo cuvier), which currently inhabit the coasts of West Africa, indicates truly tropical palaeoclimatic conditions (Pawellek et al., 2012). Supporting this interpretation, the elasmobranch assemblage described herein takes its place besides remains of marine invertebrates and vertebrates of shallow and warm waters, such as †Metaxytherium subapenninum, a tropical and coastal-estuarine form that shared the environmental preferences of current sirenians.

\section{REFERENCES} Ali M., Saad A., Reynaud C. \& $\underset{\text { honeycomb }}{\text { Additional }}$ records of (2013).
stingray 
Himantura uarnak (Chondrichthyes: Dasyatidae) off the Syrian coast (Eastern Mediterranean). Tishreen University Journal for Research and Scientific StudiesBiological Sciences Series, 35 (4): 216-22.

Benvenuti M., Papini M. \& Rook L. (2001). Mammal biochronology, IBSU and paleoenvironment evolution in a post-collisional basin: evidence from the Late Miocene Baccinello-Cinigiano basin in southern Tuscany, Italy. Bollettino della Società geologica italiana, 120 (1): 97-118.

Bianucci G., Pesci F., Collareta A. \& Tinelli C. (2019). A new Monodontidae (Cetacea, Delphinoidea) from the lower Pliocene of Italy supports a warm-water origin for narwhals and white whales. Journal of Vertebrate Paleontology, 39 (3): e1645148.

Castro J.I., Woodley C.M. \& Brudek R.L. (1999). A preliminary evaluation of the status of shark species. FAO Fish. Tech. P. 380, Rome, FAO, 72 pp.

Compagno L.J.V. (1984). Sharks of the World. An annotated and illustrated catalogue of shark species to date. Part II (Carcharhiniformes). FAO Fisheries Synopsis, FAO,
Rome.

Lawley R. (1876). Nuovi Studi Sopra i Pesci ed altri Vertebrati Fossili delle Colline Toscane. Firenze. 122 pp.

Nakano H., Matsunaga H., Okamoto H., \& Okazaki M. (2003). Acoustic tracking of bigeye thresher shark Alopias superciliosus in the eastern Pacific Ocean. Marine Ecology Progress Series, 265: 255-261.

Pawellek T., Adnet S., Cappetta H., Metais E., Salem M., Brunet M. \& Jaeger J. J. (2012). Discovery of an earliest Pliocene relic tropical fish fauna in a newly detected cliff section (Sabratah Basin, NW Libya). Neues Jahrbuch für Geologie und Paläontologie- Abhandlungen, 266 (2): 93-114.

Villafaña J. A., Marram G., Hernandez S., CarrilloBrice.o J. D., Hovestadt D., Kindlimann R., \& Kriwet J. (2019). The Neogene fossil record of Aetomylaeus (Elasmobranchii, Myliobatidae) from the southeastern Pacific. Journal of Vertebrate Paleontology, 39 (1): e1577251. 